\title{
ANTI-Plasmodium Berghei EKSTRAK DAUN DAN KAYU Lunasia amara Blanco
}

\author{
Subehan Lallo, Fitri Ariani, Resky Syamsu \\ Fakultas Farmasi, Universitas Hasanuddin, Makassar
}

Kata Kunci :

Lunasia amara Blanco, sanrego, Plasmedium barghei, malaria, parasitemia

\begin{abstract}
ABSTRAK
Lunasia amara Blanco merupakan tumbuhan yang biasa digunakan untuk berbagai penyakit secara empiris termasuk pada gejala malaria. Bagian yang paling banyak digunakan adalah kayu dan batangnya. Berdasarkan informasi tersebut telah dilakukan pengujian ekstrak kayu dan daun dari tanaman sanrego ini terhadap Plasmodium berghei yang diinfeksikan pada tikus sebagai model pengujian awal untuk antimalaria dari bahan alam. Ekstrak kayu dan batang diperoleh dengan menggunakan penyari methanol secara sonikasi. Berbagai konsentrasi digunakan secara peroral pada mencit yang telah terinfeksi oleh $P$. berghei selama 5 hari menunjukkan ekstrak daun tidak memiliki kemampuan dalam menurunkan parasetemia pada tikus sedangkan ekstrak batang memiliki kemampuan dalam menghambat parasitemia pada konsentrasi 0,5\% dengan nilai dosis supresi $50 \%$ (SD 50 ) sebesar $595 \mathrm{mg} / \mathrm{kg}$ bobot badan mencit. Hal ini menunjukkan bahwa ekstrak kayu sanrego memiliki kemampuan untuk digunakan sebagai bahan obat untuk pengobatan malaria.
\end{abstract}

\section{PENDAHULUAN}

Indonesia sebagai negara dengan iklim yang tropis dengan kondisi alam yang lebih hangat menjadi tempat yang sangat potensial untuk berkembangnya berbagai jenis parasit yang dapat menginfeksi manusia termasuk malaria. Penyakit ini disebabkan oleh protozoa genus Plasmodium yang merupakan parasit pada sel darah merah. Penularannya dapat dilakukan oleh nyamuk anopheles dengan gejala seperti menggigil, demam dan berkeringan dengan interval waktu yang bergantung pada waktu yang dibutuhkan oleh parasit dalam berkembang mem-bentuk generasi barunya. Penyakit ini akan menimbulkan anemia hemolitik berat dimana sel darah merah yang diinfeksi oleh parasit plasmodium akan mengalami kerusakan pada permukaannya menjadi tidak teratur $(1,2,3)$.

Sebagai salah satu penyakit endemis yang menyebar pada beberapa negara termasuk pada benua amerika latin, afrika, asia tenggara dan timur tengah, malaria kadang menimbulkan kejadian luar biasa pada daerah-daerah tersebut. Berbagai infomasi menunjukkan bahwa penyakit ini telah menyerang manusia sejak jaman dahulu dan berbagai jenis obat-obatan telah ditemukan dan digunakan untuk meng-obatinya namun masalah baru yang muncul adalah terjadinya resistensi terhadap obat-obatan tersebut oleh plasmodium $(4,5)$.

Pemanfaatan sumber daya alam dari tumbuhtumbuhan sudah banyak terbukti untuk mengobati penyakit malaria, salah satu diantaranya yang paling terkenal adalah kina dari kulit kayu Cinchona sp. Quinine sebagai senyawa yang terkandung telah digunakan kurang lebih 400 tahun sebagai obat untuk pengobatan malaria. Pada beberapa dekade terakhir telah ditemukan bahwa penggunaan senya-wa ini juga sudah mulai kehilangan efektifitas karena resistensi plasmodiumnya sehingga pene-litian untuk pencarian senyawa baru tetap men-jadi pusat perhatian untuk penemuan obat baru malaria. Hal ini berlanjut terus sekalipun telah ditemukan juga senyawa baru lain dari Artimisia annua yang digunakan sebagai obat baru anti malaria yaitu artimisinine. Senyawa ini juga sekarang sedang intensif diteliti untuk kemung-kinan sebagai anti kanker $(6,7)$.

Keberlanjutan pencarian obat baru sebagai antimalarial sangat penting untuk tetap dilanjutkan untuk persiapan dalam mencegah kemungkinan terjadinya penurunan aktifitas karena resistennya plasmodium tersebut sehingga penggalian bahan-bahan obat alam dari obat tradisional merupakan salah satu langkah penting dalam penemuan obat baru tersebut. Berbagai jenis tanaman telah dilaporkan secara empiris dapat digunakan untuk mengobati gejala penyakit malaria tersebut seperti kayu sanrego, bunga matahari, jeruk nipis, kenanga, meniran, murbei, pare, papaya, pinang, pulai, pulutan, sambiloto, dan beringin $(6,7)$.

Kayu sanrego (Lunasia amara Blanco) merupakan salah satu tanaman obat tradisional yang digunakan oleh masyarakat Indonesia untuk berbagai penyakit seperti aprodisiaka, anti inflamasi dan penangkal bisa ular. Tanaman ini tumbuh disepanjang pegunungan Indonesia. Penelitian tentang keragaman fenotipe dari tanaman ini telah dilaporkan untuk kelestariannya. Berbagai turunan senyawa alkaloid akrilidon seperti lunanin, lunamarin, lunine dan lunakrin telah dilaporan diisolasi dari tanaman ini. Rasa pahit pada batang dan daunnya merupakan salah satu karakteristik tanaman dan ciri-ciri dari kandungan kimia senyawanya berupa alkaloid $(8,9)$.

Penelitian tentang aktifitas biologinya juga telah dilaporkan baik dalam bentuk ekstraknya maupun dalam bentuk senyawa tunggalnya dengan aktifitas seperti aprodisiaka, anti bakteri, anti kanker 
dan kemampuan dalam menghambat sitokrom P450. Berdasarkan hal tersebut sehingga kami tertarik untuk melakukan uji aktifitas daun dan kayu sanrego ( $L$ amara) sebagai antiplasmodium berghei secarain vivo pada tikus sebagai model uji untuk obat malaria $(10,11,12)$.

\section{METODE PENELITIAN}

\section{Alat dan Bahan}

Alat yang digunakan adalah alu, batang penganduk, beker, cawan porselen, gelas ukur, jarum suntik (Terumo ${ }^{\circledR}$ ), kanula, kandang mencit, labu tentukur $\left(\right.$ Pyrex $\left.^{\circledR}\right)$, lumpang, mikroskop (Olympus ${ }^{\circledR}$ ), alat maserasi dan sonikasi, timbangan analitik (Dragon $303^{\circledR}$ ), timbangan hewan.

Bahan yang digunakan adalah alumunium foil, air suling, batang dan daun Sanrego (Lunasia amara Blanco), kertas saring, kertas timbang, metanol, Natrium CMC, Natrium EDTA, Phosfat Buffer Saline (PBS), Plasmodium berghei, pereaksi warna Giemsa.

\section{Penyiapan Sampel}

Kayu sanrego (Lunasia amara Blanco) dikumpulkan dari hutan di Dusun Birue, Desa Siawung, Kecamatan Barru, Kabupaten Barru. Sampel yang telah dikumpulkan kemudian dibersihkan dari pengotoran, dipotong kecil-kecil, kemudian dikeringkan dengan tidak terpapar langsung dari sinar matahari.

\section{Ekstraksi dan Partisi Sampel}

\section{Ekstraksi Sampel}

Sebanyak $2 \mathrm{~kg}$ atau atau kayu sanrego yang telah dipotong kecil-kecil diekstraksi secara maserasi dibantu dengan sonikasi dengan $10 \mathrm{~L}$ metanol. Ekstraksi dilakukan sebanyak 3 kali selama 4 jam dalam wadah sonikator. Ekstrak yang diperoleh dikumpulkan dan dipekatkan dengan rotavapor sampai kental, selanjutnya diuapkan di atas tangas air sehingga diperoleh ekstrak metanol kental.

\section{Pembuatan Sampel Penelitian}

\section{Pembuatan Larutan Koloidal Natrium CMC 1\%}

Sebanyak $1 \mathrm{~g}$ Natrium CMC dimasukkan sedikit demi sedikit ke dalam $50 \mathrm{ml}$ air suling panas (suhu $70^{\circ} \mathrm{C}$ ) sambil diaduk dengan pengaduk elektrik hingga terbentuk larutan koloidal dan dicukupkan volumenya dengan air suling hingga $100 \mathrm{ml}$.

\section{Penyiapan Sediaan Uji}

\section{Suspensi Ekstrak}

Untuk suspensi ekstrak metanol batang Sanrego 0,1\%; 0,5\% dan $1 \%$ masing-masing ditimbang $0,1 \mathrm{~g}, 0,5 \mathrm{~g}$, dan $1 \mathrm{~g}$ kemudian masing-masing digerus dalam lumpang, ditambahkan larutan koloidal NaCMC 1\% sedikit demi sedikit ke dalamnya sambil digerus hingga homogen, dimasukan dalam labu tentukur dan dicukupkan volumenya hingga 100 $\mathrm{ml}$.

\section{Uji Antimalaria \\ Pemilihan dan Penyiapan Hewan Uji \\ Pemilihan Hewan Uji}

Hewan uji yang digunakan adalah mencit (Mus musculus) jantan yang berumur 2-3 bulan, sehat dan bersih dengan berat badan rata-rata $20-30$ g. Sebelum digunakan terlebih dahulu diadaptasikan dengan lingkungan sekitarnya selama $1-2$ minggu.

\section{Penyiapan Hewan Uji}

Hewan uji yang digunakan sebanyak 40 ekor. 20 ekor digunakan untuk ekstrak daun dan 20 lainnya untuk ekstrak batang. Setiap kelompok ekstrak dikelompokan lagi dalam 4 kelompok yang terdiri dari 5 mencit jantan. Kelompok I (kelompok kontrol/Na-CMC 1\% b/v), kelompok II (kelompok ekstrak sanrego 0,1\%), kelompok III (kelompok ekstrak sanrego 0,5\%), dan kelompok IV (kelompok ekstrak sanrego $1 \%)$.

\section{Perlakuan Terhadap Hewan Uji}

Sebelum diberi perlakuan, semua kelompok hewan uji diinjeksikan Plasmodium berghei secara intraperitonial 0,2 $\mathrm{ml} / 25 \mathrm{~g} \mathrm{BB}$. Setelah persentase parasitemianya mencapai 1$5 \%$, mencit jantan yang telah diinfeksi parasit diberikan ekstrak sanrego sebanyak $1 \mathrm{ml} / 25 \mathrm{~g}$ BB secara oral. Kelompok I sebagai pembanding/kontrol, diberikan Na-CMC $1 \% \mathrm{~b} / \mathrm{v}$. Kelompok II, III, dan IV diberikan ekstrak sanrego dengan konsentrasi berturut-turut $0,1 \% ; 0,5 \%$ dan $1 \%$ pada masing-masing mencit.

\section{Pengambilan Sampel Darah Hewan Uji}

Sampel darah hewan uji mencit jantan diambil dari ekor dengan cara melukai ujung ekor.

\section{Pembuatan Apusan Darah Hewan Uji}

Apusan dibuat dengan mengambil sampel darah hewan uji mencit jantan sebanyak satu tetes, dan dibuat menjadi lapisan tipis pada objek gelas. Apusan darah kemudian difiksasi dengan metanol dan diwarnai dengan Giemsa 10\% selama 30 menit. Sediaan darah dicuci dengan air mengalir dan dikeringkan.

Penentuan Parasitemia dalam Sediaan Darah Hewan Uji Parasitemia dalam sampel darah hewan uji mencit jantan ditentukan dengan metode hitung parasit dalam sel darah merah secara mikroskopik

\section{Pengumpulan Data}

Data diperoleh dari hasil perhitungan parasitemia dalam sel darah merah hewan uji mencit jantan setelah persentasi parasitemianya mencapai $1-5 \%$ (dihitung sebagai $\mathrm{H}-0$ ) dan dilanjutkan dengan tahapan pengobatan dengan pemberian suspensi ekstrak sanrego selama 4 hari berturut-turut (sampai H-4)

\section{Analisis Dato}

Data yang dikumpulkan dari hasil perhitungan parasitemia kemudian dianalisa secara statistik menggunakan analisis probit untuk menentukan nilai SD50.

\section{HASIL DAN PEMBAHASAN}

Penelitian ini bertujuan untuk mengetahui efek ekstrak metanold dari daun dan kayu sanrego (Lunasia amara Blanco) sebagai obat anti-malaria dengan parameter perkembangan parasitemia dalam sel darah merah hewan uji mencit jantan. Konsentrasi suspensi ekstrak yang diujikan adalah dari 0,01 sampai $1,0 \%(b / v)$.

Mencit diinfeksikan dengan Plasmodium berghei karena jenis Plasmodium ini hanya dapat menginfeksi hewan coba (parasit untuk hewan pengerat). Jenis plasmodium yang menginfeksi manusia seperti Plasmodium falciparum tidak dapat menginfeksi hewan coba yang digunakan sehingga hanya dapat digunakan untuk uji in vitro. Plasmodium berghei umum digunakan dalam penelitian-penelitian tentang malaria karena siklus hidup dan morfologinya mirip dengan jenis plasmodium yang menginfeksi manusia khususnya Plasmodium falciparum.

Uji in vivo ini dilaksanakan dengan menggunakan mencit putih jantan dengan berat rata-rata 25 g. Sejumlah $0,2 \mathrm{ml}$ darah mencit terinfeksi Plasmodium berghei diinokulasikan ke dalam mencit sehat secara intraperitonial. Beberapa hari setelah infeksi, persentase parasitemia mencit diperiksa melalui apusan tipis darah tepi. Apabila telah mencapai 1-5\%, pada saat ini pengobatan mulai diberikan dan ditandai 
sebagai H-0. Setiap senyawa yang diberikan diencerkan dengan Na-CMC 1\%, sedangkan sebagai kontrol diberikan suspensi Na-CMC dalam air suling tanpa bahan aktif. Karena mengingat respon patologis yang tinggi dari infeksi malaria berat dengan adanya resiko kematian hewan uji mencit yang terjadi apabila konsentrasi parasitemia melebihi $5 \%$, dimana pada kondisi ini tahapan pengobatan dapat dikatakan sudah terlambat.

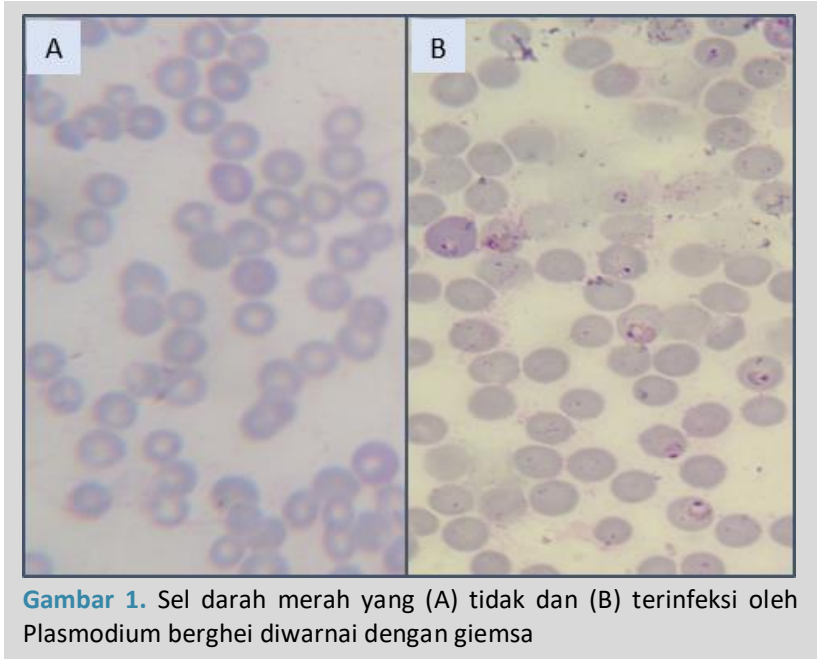

Hasil penelitian rata-rata persentasi parasitemia pada mencit setelah pemberian ekstrak metanol daun Sanrego 0,01\% (b/v) pada hari pertama adalah $12,48 \%$, hari kedua 30,59\%, hari ketiga 45,51 \% dan hari keempat 57,52 \%. Rata-rata persentasi parasitemia pada konsentrasi pemberian $0,1 \%$ (b/v) pada hari pertama adalah 15,69\%, hari kedua 30,44\%, hari ketiga 42,06 \% dan hari keempat 42,01\%. Sedangkan pada konsentrasi $1,0 \%$ mencit yang digunakan sebagai hewan percobaan telah mati setelah pemberian ekstrak metanol pada hari pertama.

Pemberian ekstrak metanol batang sanrego 0,1\% (b/v) pada hari pertama adalah 1,94\%, hari kedua $10,73 \%$, hari ketiga $23,77 \%$, hari keempat 48,29\%. Rata-rata persentasi parasitemia pada konsentrasi pemberian $0,5 \%$ (b/v) pada hari pertama adalah 1,38\%, hari kedua 8,29\%, hari ketiga 15,66\%, hari keempat 26,24\%. Pada konsentrasi ini dilakukan pengamatan parasitemia sampai hari keenam karena terdapat satu hewan uji yang mengalami penurunan persen parasitemia. Rata-rata persentasi parasitemia pada hari keenam adalah $15,75 \%$. Sedangkan rata-rata persentasi parasitemia pada konsentrasi pemberian $1 \%(\mathrm{~b} / \mathrm{v})$ pada hari pertama adalah 3,45\%, hari kedua 27,88\%, hari ketiga $46,82 \%$. Sedangkan pada kelompok kontrol yaitu rata-rata persentasi parasitemia pada hari pertama adalah $1,34 \%$, hari kedua $8,70 \%$, hari ketiga $26,26 \%$, dan hari keempat $42,92 \%$.

Adanya penurunan persen parasitemia sampai hari keenam pada konsentrasi ekstrak 0,5\% b/v, menunjukkan bahwa pengobatan malaria dengan ekstrak batang Sanrego akan lebih baik jika pemberian ekstrak lebih lama, karena semakin hari penekanan terhadap Plasmodium berghei dalam sel darah merah mencit akan terus terjadi. Dengan demikian aktivitas batang sanrego sebagai obat malaria dapat dibuktikan dengan adanya penurunan persentasi parasitemia dalam sel darah merah hewan uji mencit jantan pada konsentrasi ekstrak 0,1\% dan 0,5\% (b/v). Jadi, penekanan pertumbuhan $50 \%$ Plasmodium berghei terjadi pada hari kelima (H-4) dan keenam (H-5) perlakuan setelah pemberian ekstrak.

Sedangkan pada konsentrasi ekstrak 1\% tidak mengalami penurunan persentasi parasitemia. Hewan uji yang digunakan bahkan hanya bertahan hidup sampai hari ketiga. Hal ini dapat mengindikasikan bahwa ekstrak metanol Sanrego pada konsentrasi $1 \%$ atau lebih memiliki potensi toksik. Kematian hewan uji juga terjadi karena perkembangan Plasmodium yang semakin tinggi dari hari ke hari tanpa adanya efek supresi ekstrak terhadap parasit dalam sel darah merah mencit.

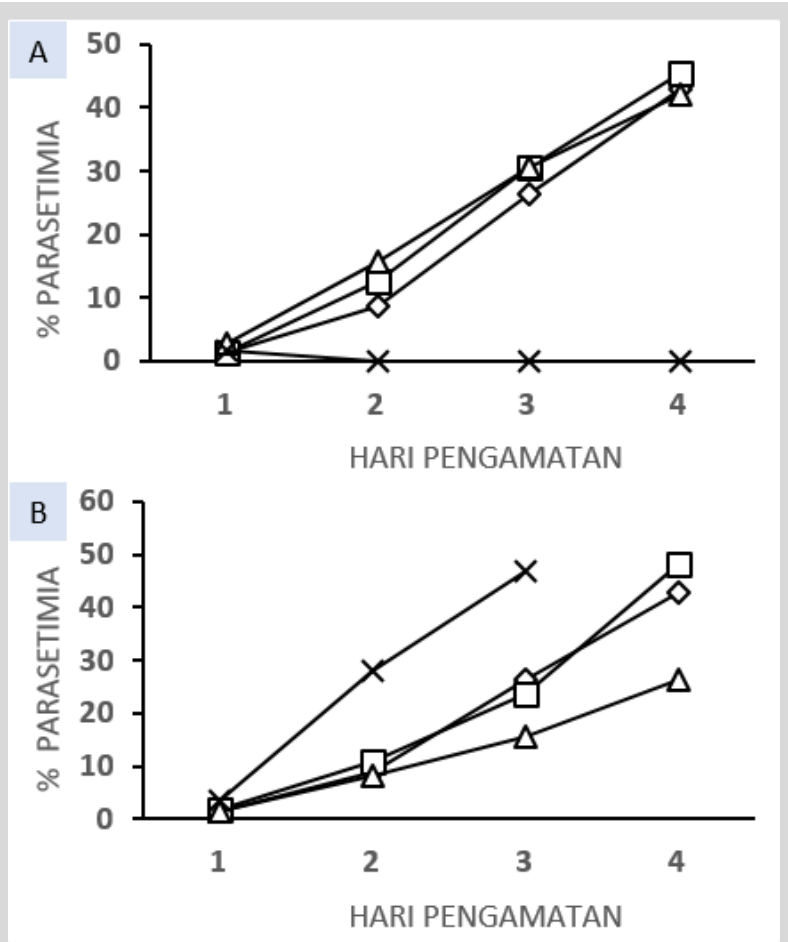

Gambar 2. Daya hambat (A) ekstrak daun (0,01, 0,1 dan 1\%) dan (B) kayu sanrego $(0.01,0,5$, dan $1 \%)$ terhadap pertumbuhan parasitemia pada mencit

Potensi antimalaria dihitung berdasarkan kemampuan ekstrak atau senyawa menekan pertumbuhan parasitemia yang disebut dosis supresi (Suppression Dose 50\% = SD 50 ) dapat diketahui dengan menghitung jumlah rata-rata pertumbuhan parasitemia pada perlakuan kontrol dikurang dengan jumlah rata-rata pertumbuhan perlakuan masingmasing dosis dibagi dengan jumlah rata-rata pertumbuhan parasitemia kontrol dikali dengan $100 \%$.

Dari perhitungan analisis probit diperoleh dosis supresi 50\% pertumbuhan ( $\mathrm{SD}_{50}$ value) Plasmodium berghei sebesar $595,26 \mathrm{mg} / \mathrm{Kg}$ bobot badan hewan coba mencit, dimana pada konsentrasi tersebut pertumbuhan Plasmodium berghei dalam sel darah merah dapat dihambat kira-kira menjadi $50 \%$ dari pertumbuhan normalnya.

Dari hasil penelitian menunjukkan bahwa ekstrak metanol daun Sanrego (Lunasia amara Blanco) dari konsentasi 0,01\% (b/v) sampai dengan konsentrasi $1 \%$ (b/v) tidak mempunyai efek antimalaria, hal ini dapat dilihat dari rata-rata persentasi parasitemia yang terus meningkat setelah pemberian ekstrak. Adanya mencit yang mati diduga karena efek toksisitas ekstrak metanol daun Sanrego (Lunasia amara Blanco) terhadap hewan coba mencit (Mus musculus) dan perkembangan Plasmodium yang sangat cepat. Sedangkan untuk ekstrak metanol batang Sanrego, memperlihatkan penekanan pertumbuhan parasit pada konsentrasi 595 $\mathrm{mg} / \mathrm{KgBB}$. Nilai $\mathrm{SD}_{50}$ yang besar menunjukkan lemahnya efek supresi ekstrak terhadap pertumbuhan parasit.

Dalam perhitungan regresi, data yang digunakan untuk menghasilkan grafik yang sesuai minimal tiga. Sehingga akan terlihat perbedaan plot garis dari persamaan regresi dan linear. Pada data pengamatan persentasi parasitemia dalam sel darah merah mencit, hewan uji yang diberi ekstrak metanol batang Sanrego $1 \% \mathrm{~b} / \mathrm{v}$ hanya bertahan hidup sampai hari ketiga dan sampai hari tersebut tidak menunjukkan penurunan persentasi parasitemia. 
Ketidaklengkapan data tersebut akan mempengaruhi nilai $\mathrm{SD}_{50}$ sehingga dalam perhitungan analisis probit hanya digunakan dua data untuk mendapatkan nilai $\mathrm{SD}_{50}$ yang lebih akurat. Nilai $\mathrm{SD}_{50}$ yang dihitung dari tiga data berdasarkan perlakuan dengan konsentrasi ekstrak 0,1\%, 0,5\% dan 1\% adalah $689,31 \mathrm{mg} / \mathrm{KgBB}$ sedangkan nilai $\mathrm{SD}_{50}$ yang dihitung dari dua data berdasarkan perlakuan dengan konsentrasi ekstrak 0,1\% dan 0,5\% adalah 595,26 mg/KgBB. Perbedaan ini disebabkan karena memang hanya pada konsentrasi $0,1 \%$ dan $0,5 \%$ menunjukkan penurunan persentasi parasitemia, jadi nilai $\mathrm{SD}_{50}$-nya lebih kecil. Akan tetapi nilai 595,26 $\mathrm{mg} / \mathrm{KgBB}$ (antilog 2,774) tidak masuk dalam range log konsentrasi atau $\mathrm{SD}_{50}$ berada diluar grafik persamaan garis regresi. Peristiwa ini yang disebut 'out of layer' karena prediksi dosis supresinya lebih besar dari nilai log konsentrasi yang ada. Pada kenyataanya, penurunan persentasi parasitemia pada perlakuan dengan konsentrasi ekstrak 0,5\% baru terjadi setelah pengamatan hari keenam.

\section{KESIMPULAN}

Berdasarkan hasil penelitian efek pemberian ekstrak metanol daun Sanrego (Lunasia amara Blanco) terhadap perkembangan parasitemia dalam sel darah merah mencit jantan dapat disimpulkan bahwa ekstrak daun Sanrego (Lunasia amara Blanco) dengan konsentrasi 0,01 - 1,0 \% (b/v) tidak dapat menghambat perkembangan parasitemia dalam sel darah merah mencit jantan yang terinfeksi Plasmodium berghei. Sedangkan pemberian ekstrak metanol batang Sanrego (Lunasia amara Blanco) menunjukkan bahwa pada konsentrasi $0,1 \%$ dan $0,5 \%$ (b/v) mempunyai efek menekan pertumbuhan parasitemia dengan SD $_{50}$ sebesar 595,26 $\mathrm{mg} / \mathrm{Kg}$.

\section{UCAPAN TERIMA KASIH}

Terima kasih kami ucapkan kepada Alm. Faisal Attamimi dan Almh. Rahmawati Syukur atas segala bantuan dalam pelaksanaan penelitian ini semasa hidupnya. Mudahmudahan keduanya tenang disisiNya dengan segala pahalanya

\section{DAFTAR PUSTAKA}

1. Kumala P. Kamus saku kedokteran, dorland. Ed 25. Jakarta: Penerbit Buku Kedokteran EGC; 1998. Malaria, 645

2. Syarif A dan DS Zunilda. Kemoterapi parasit. Di dalam: Gunawan SG, editor. Farmakologi dan terapi. Ed 5. Jakarta: Bagian Farmakologi. FKUI; 2007, 556

3. Price SA, Wilson LM. Patofisiologi, konsep klinis proses-proses penyakit. Ed 6. Jakarta: Penerbit Buku Kedokteran. EGC; 2005: 1.258

4. Autino B, Noris A, Russo R, Castelli F, Epidemiology of Malaria in Endemic Areas, Mediterr J Hematol Infect Dis 2012; 4, 1-11

5. Achan J., Talisuna AO, Erhart A, Yeka A, Tibenderana JK, Baliraine FN, Rosenthal FJ., D'Alessandro U. Quinine, an old anti-malarial drug in a modern world: role in the treatment of malaria. Malaria Journal 2011, $10,144,1-12$

6. Brown, G.D. Artemisinin and a new generation of antimalarial drugs. Education in Chemistry, 2006, 43 (4). pp. 97-99.

7. Cahyaningsih $\mathrm{R}$, Characterization of phenotypic diversity of a medicinal plant Lunasia amara. Nusantara Bioscience. 8 (2), 245-251.

8. Takahashi N, Subehan, Kadota S, Tezuka Y. Mechanism-based CYP2D6 inactivation by acridone alkaloids of Indonesian medicinal plant Lunasia amara. Fitoterapi 2012. 83(4). 774-779.

9. Nurbita. Uji Daya Hambat Ekstrak Metanol Batang Kayu Sanrego (Lunasia amara Blanco) Terhadap Bakteri Gram Postif (+) dan Gram Negatif (-). Skripsi Jurusan Farmasi Fakultas. MIPA Universitas Hasanuddin. Ujung Pandang. 1994. hal. 29

10. Arnida. Isolasi Fraksi Aktif Afrodisiaka dari Kayu Sanrego (Lunasia amara Blanco.) pada Tikus Jantan. Majalah Farmasi Indonesia. 2003. Hal. 195.

11. Subehan, Takahashi N, Kadota S, Tezuka Y Cytochrome P450 2D6 inhibitory constituents of Lunasia amara. Phytochemistry Letters 2011, 4 (1), 30-33.Schug S.A., Manopas A. (2015), Update on the Role of NonOpioids for Postoperative Pain Treatment, B est Practice \& R esearch Clinical A naesthesiology, Vol. 21 No. 1:15-30. 